\title{
Kadar kolesistokinin laki-laki dewasa dengan konsumsi makanan siap saji khas Indonesia dan internasional ${ }^{1}$
}

\author{
Levels of cholecystokinin on males adults who consuming Indonesian and international fast food
}

\author{
Inggita Kusumastuty², Dian Handayani², Rizky Ayu Diella Calista ${ }^{2}$
}

${ }^{2}$ Jurusan Gizi Fakultas Kedokteran Universitas Brawijaya

\begin{abstract}
Background: Fast food comes to meal that is prepared fast and identically high in energy and fat contents since fast food is prepared using oil and fats. Excessive eating of fast food which is Indonesian typical fast foods and international fast foods will deliver obesity risk. Satiety and hunger are known as the two main keys of obesity prevention. Furthermore, Cholecystokinin (CCK) hormone is the one of bio-indicator that can indicate both satiety and hunger. Objective: The aim of this study is to determine the difference between CCK plasma level of Indonesian and international fast food. Method: A post-test only group design was done at 16 male adult subjects. This research measured CCK plasma of adult subjects with normal nutritional status whether consumed Indonesian typical fast foods and international fast foods. CCK plasma was measured by Enzyme-linked Immunosorbent Assay (ELISA) between 0-120 minutes. Results: Subjects who consumed Indonesian typical fast foods had significantly lower CCK plasma at 30,60 and 120 minutes measurement than that counterpart $(p=0.000)$. Conclusion: There is a different level of CCK after consuming Indonesian typical fast food and International fast food.
\end{abstract}

KEY WORDS: cholecystokinin; Indonesian fast food; international fast food

\begin{abstract}
ABSTRAK
Latar belakang: Makanan siap saji merupakan makanan yang dipersiapkan dengan cepat dan teridentifikasi tinggi energi serta lemak dikarenakan penambahan minyak dan lemak pada proses pengolahan. Kelebihan konsumsi makanan siap saji baik makanan siap saji khas Indonesia maupun siap saji berstandar Internasional dapat menyebabkan terjadinya obesitas. Kontrol rasa kenyang dan lapar merupakan dua kunci utama dalam pencegahan obesitas. Salah satu hormon yang dapat digunakan sebagai parameter rasa kenyang dan lapar adalah cholecystokinin (CCK). Tujuan: Mengetahui perbedaan kadar CCK plasma pada makanan siap saji khas Indonesia dan makanan siap saji internasional. Metode: Desain penelitian ini adalah post-test only group design pada 16 responden laki-laki dewasa dengan status gizi normal yang mengkonsumsi makanan siap saji khas Indonesia dan internasional. Kadar CCK plasma diukur dengan metode enzyme-linked immunosorbent assay (ELISA) pada menit ke 0-120. Hasil: Responden yang mengkonsumsi makanan siap saji khas Indonesia memiliki kadar CCK yang signifikan lebih rendah dibandingkan kelompok internasional $(\mathrm{p}=0,000)$. Simpulan: Terdapat perbedaan kadar CCK pada responden setelah mengkonsumsi makanan siap saji Indonesia dengan setelah mengkonsumsi makanan siap saji internasional.
\end{abstract}

KATA KUNCI: kolesistokinin; makanan siap saji Indonesia; makanan siap saji internasional

\section{PENDAHULUAN}

Obesitas merupakan suatu kondisi yang dapat terjadi karena ketidakseimbangan antara energi yang masuk dengan energi yang keluar dari dalam tubuh dan ditandai dengan adanya penimbunan jaringan lemak dalam tubuh secara berlebihan. Beberapa studi menunjukkan bahwa konsumsi makanan dengan kepadatan energi tinggi dapat menyebabkan terjadinya obesitas dikarenakan konsumsi makanan padat energi dapat merusak regulasi

\footnotetext{
Dipresentasikan pada $7^{\text {th }}$ International Symposium on Wellness, Healthy Lifestyle and Nutrition pada tanggal 3-4 November 2016 di Yogyakarta kerjasama dengan Universiti Sains Malaysia, Malaysia dan Prince of Songkla University, Thailand

Korespondensi: Inggita Kusumastuty, Jurusan Gizi Fakultas Kedokteran, Universitas Brawijaya, Jl. Veteran Malang 65145, Jawa Timur, Indonesia, e-mail: inggita. kusuma@gmail.com
} 
normal selera makan serta cenderung menyebabkan asupan energi menjadi lebih besar $(1,2)$. Kematian serta penyakit degeneratif seperti diabetes mellitus tipe 2, hipertensi, jantung koroner, kanker, dan stroke adalah risiko obesitas. Angka prevalensi obesitas di Indonesia berdasarkan data riset kesehatan dasar (Riskesdas) tahun 2013 menunjukkan angka yang tinggi yaitu 8,8\% pada anak umur 5-12 tahun; 2,5\% pada remaja umur 13-15 tahun; dan 1,6\% pada remaja umur 16-18 tahun sedangkan prevalensi berat badan lebih pada dewasa mencapai $13,5 \%$ sementara prevalensi obesitas diketahui $15,4 \%(3,4)$.

Pemilihan makanan yang memberikan efek kenyang lebih lama merupakan upaya dalam mengatasi obesitas. Saat ini, banyak berkembang makanan siap saji baik khas Indonesia (SSKInd) maupun yang berstandar internasional (SSInt) di Indonesia. Hasil penelitian sebelumnya menunjukkan bahwa kandungan energi makanan SSInt cenderung memiliki densitas energi yang lebih tinggi dibandingkan makanan SSKInd, SSInt memiliki kadar air yang rendah sehingga volume makanannya cenderung lebih kecil tetapi memiliki kandungan energi yang tinggi (5). Selain itu, makanan yang memiliki densitas energi yang tinggi juga cenderung mengandung lemak yang tinggi serta serat yang rendah $(1,2)$. Kepadatan energi serta zat gizi yang terkandung dalam makanan dapat mempengaruhi kontrol nafsu makanan pada seseorang, tetapi kajian mengenai hal ini terutama pada SSind dan SSInt belum dilakukan. Oleh karena itu, perlu dilakukan pengkajian efek pengontrolan nafsu makan dari makanan SSKInd dan SSInt.

Pengaturan rasa lapar atau kenyang merupakan salah satu faktor yang berpengaruh kuat terhadap obesitas. Hormon kolesistokinin (cholecystokinin) dapat digunakan untuk menilai rasa kenyang jangka pendek. Cholecystokinin (CCK) merupakan hormon polipeptida yang diproduksi oleh sel-sel mukosa duodenum dan jejenum serta dihasilkan pula oleh otak dan sistem saraf enterik. Rasa kenyang yang dihasilkan oleh CKK dapat diketahui dengan adanya CCK reseptor 1 (CCK1R) yang tinggi di sistem pencernaan, ekspresi pada otak belakang dan hipotalamus. Proses ini mengindikasikan bahwa CCK mengirimkan sinyal rasa kenyang ke otak secara langsung maupun tidak langsung (6).
Tujuan dari penelitian ini adalah untuk mengetahui apakah terdapat perbedaan efek kenyang pada subjek dengan status gizi normal, setelah mengkonsumsi makanan SSKInd dan makanan SSInt yang beredar di masyarakat melalui pengukuran kadar CCK plasma. Efek yang berbeda akan mampu menghasilkan informasi yang bermanfaat bagi kelompok yang ingin menurunkan asupan makannya dengan melakukan pemilihan makanan yang lebih mengenyangkan.

\section{BAHAN DAN METODE}

Penelitian ini merupakan penelitian eksperimental dengan menggunakan desain posttest only group design yang dilaksanakan pada bulan Juni-September 2015 di Universitas Brawijaya. Penelitian ini telah mendapatkan persetujuan etik dari Komisi Etik Penelitian Fakultas Kedokteran Universitas Brawijaya dengan kelayakan etik No. 389/EC/KEPK/07/2015. Populasi penelitian ini adalah responden laki-laki dewasa dengan status gizi normal. Jumlah responden pada penelitian ini sejumlah 16 orang sesuai hasil perhitungan jumlah sampel $\{(\mathrm{t}-1)(\mathrm{r}-1) \geq 15\}$ dengan kelompok perlakuan $(\mathrm{t})=2$ dan pengulangan $(\mathrm{r})$. Dari rumus tersebut maka responden yang dibutuhkan dalam penelitian ini minimal sejumlah 15 orang. Responden yang digunakan dipilih sesuai dengan kriteria inklusi dan eksklusi serta setuju berpastisipasi dalam penelitian ini dengan menandatangani inform consent. Kriteria inklusi pada penelitian ini adalah berjenis kelamin laki-laki; umur 19-29 tahun ; indeks massa tubuh (IMT) normal sesuai klasifikasi World Health Organization (WHO) Asia (18,5 - 22,99 kg/ $\mathrm{m}^{2}$ ); tidak memiliki kebiasaan merokok (berdasarkan hasil wawancara); tidak memiliki alergi makanan (berdasarkan hasil wawancara); tidak sedang dalam pengobatan medis (berdasarkan hasil wawancara); tidak bergantung kepada obat penurun lemak dan antiobesitas; tidak mengalami hiperkolesterolemia (kolesterol $<200 \mathrm{mg} / \mathrm{dl}$ ); serta tidak menderita diabetes mellitus (gula darah puasa $<100 \mathrm{mg}$ / dL). Adapun kriteria eksklusi pada penelitian ini adalah responden sakit pada saat penelitian dan tidak mau mengikuti prosedur penelitian yang telah ditentukan (tidak puasa atau waktu jam puasa tidak sesuai).

Prosedur pengambilan data pada penelitian ini adalah (a) sehari sebelum intervensi dilakukan, 
Tabel 1. Karakteristik makanan

\begin{tabular}{lccccc}
\hline \multirow{2}{*}{$\begin{array}{c}\text { Jenis } \\
\text { makanan }\end{array}$} & $\begin{array}{c}\text { Berat makanan per } \\
\text { porsi/sajian }\end{array}$ & \multicolumn{4}{c}{ Per porsi / per sajian } \\
\cline { 2 - 6 } & $\mathbf{( g )}$ & $\mathbf{\text { Energi }}$ & Lemak & Protein & Karbohidrat \\
\hline SSKInd $^{1}$ & 592,3 & 568,2 & $\mathbf{g} \mathbf{( \% )}$ & $\mathbf{g} \mathbf{( \% )}$ & $\mathbf{g ( \% )}$ \\
SSInt $^{2}$ & 283,8 & 548,8 & $19,3(13,8)$ & $24,8(17,1)$ & $84,8(59,6)$ \\
\hline
\end{tabular}

${ }^{1}$ SSKInd $=$ siap saji khas Indonesia $;{ }^{2}$ SSInt $=$ siap saji khas internasional

responden diberikan makan malam sejumlah $500 \mathrm{kkal}$ dan dikonsumsi oleh responden antara pukul 20.00 s.d 21.00; (b) responden berpuasa setelah makan malam dilakukan ; (c) responden diminta berkumpul di Poliklinik Universitas Brawijaya pada pukul 07.00 untuk dilakukan pengambilan darah puasa (0 menit); (d) responden diberikan makanan SSKInd dan diberi waktu untuk menghabiskan makanannya dalam 30 menit; (e) dilakukan pengambilan darah pada menit ke-30, 60, dan terakhir pada menit ke-120 setelah mengkonsumsi makanan. Tujuh hari kemudian, 16 responden tersebut akan melakukan prosedur serupa untuk intervensi konsumsi makanan SSInt.

Variabel bebas pada penelitian ini adalah pemberian makanan SSInt dan makanan SSKInd. Makanan SSInt adalah makanan siap saji dengan resep internasional (western) yang merupakan makanan franchise yang banyak dijual di berbagai Kota di Indonesia dengan energi 548,8 kkal per sajian. Adapun makanan SSInt yang digunakan dalam penelitian ini adalah paket burger dan kentang goreng, paket nasi dan ayam goreng, yakiniku, dan pasta. Sementara makanan SSKInd adalah makanan siap saji dengan resep khas masakan nusantara yang popular dikonsumsi oleh masyarakat Indonesia dengan energi sebesar 568,2 kkal per sajian Adapun makanan SSKInd yang digunakan dalam penelitian ini berupa sate, bakso, rawon, dan sop ayam. Rerata kandungan energi makanan SSInt dan SSKInd adalah 558,5 kkal dengan asumsi makanan tersebut adekuat untuk memenuhi kebutuhan energi sekali makan berdasarkan angka kecukupan gizi (AKG) untuk dewasa usia 19-29 tahun. Adapun karakteristik makanan yang dikonsumsi oleh responden dalam penelitian ini dapat dilihat pada Tabel 1. Variabel terikat pada penelitian ini adalah CCK yang diukur pada menit ke-0 (10 jam setelah puasa), 30, 60, dan 120 menit setelah mengkonsumsi makanan. Sekitar $10 \mathrm{ml}$ darah diambil melalui vena cubiti dan disimpan pada vacutainer
EDTA. Segera setelah sampel darah dikumpulkan, dilakukan sentrifugasi pada $3000 \mathrm{rpm}$ selama 10 menit kemudian plasma diletakkan pada cryotube dan disimpan pada $-80^{\circ} \mathrm{C}$ hingga dilakukan analisis.

Metode pengukuran CCK menggunakan enzymlinked immunosorbent assay (ELISA) (Elabscience, Biotechnology, Beijing) sesuai dengan ELISA kit yang digunakan (No. Katalog E-EL-H0723). Standar atau sampel diletakkan pada sumuran dan ditambahkan spesifik antibodi. Reaksi enzim-substrat diakhiri dengan penambahan larutan sulphuric acid dan adanya perubahan warna. Absorbansi diukur dengan spektofotometer pada panjang gelombang $450 \mathrm{~nm} \pm 2 \mathrm{~nm}$ kemudian konsentrasi CCK pada sampel dihitung dengan membandingkan absorbansi sampel dengan kurva standar (7). Data CCK menit ke-0, 30, 60 dan 120 disajikan dalam bentuk Mean \pm SD. Analisis data untuk mengetahui perbedaan kadar CCK dengan pemberian makanan SSInt dan SSKInd diuji menggunakan independent t-test pada setiap waktu pengukuran.

\section{HASIL}

Enam belas responden laki-laki dewasa dalam penelitian ini telah melalui proses skrining untuk memenuhi kriteria inklusi. Hasil dari skrining menunjukkan rerata berat badan dan tinggi badan sebesar $60,9 \pm 5,7 \mathrm{~kg}$ dan $169,2 \pm 6,3 \mathrm{~cm}$ dengan IMT $\left(21,3 \pm 1,1 \mathrm{~kg} / \mathrm{m}^{2}\right)$, tekanan darah sistolik (107,5 $\pm 6,8 \mathrm{mmHg})$, tekanan darah diastolik (75 $\pm 5,2 \mathrm{mmHg})$, kadar glukosa darah $(103,4 \pm 1,2 \mathrm{~g} / \mathrm{dl})$, dan kadar kolesterol dalam kategori normal $(94,8 \pm 4,9 \mathrm{~g} /$ dl) serta responden tidak dalam kondisi diit.

Berdasarkan data yang tersaji pada Gambar 1 menunjukkan bahwa kadar CCK setelah mengkonsumsi makanan SSKInd memiliki trend penurunan pada menit ke-30 dan 60, kemudian mulai meningkat kembali pada menit ke-120. Berbeda pada kelompok 


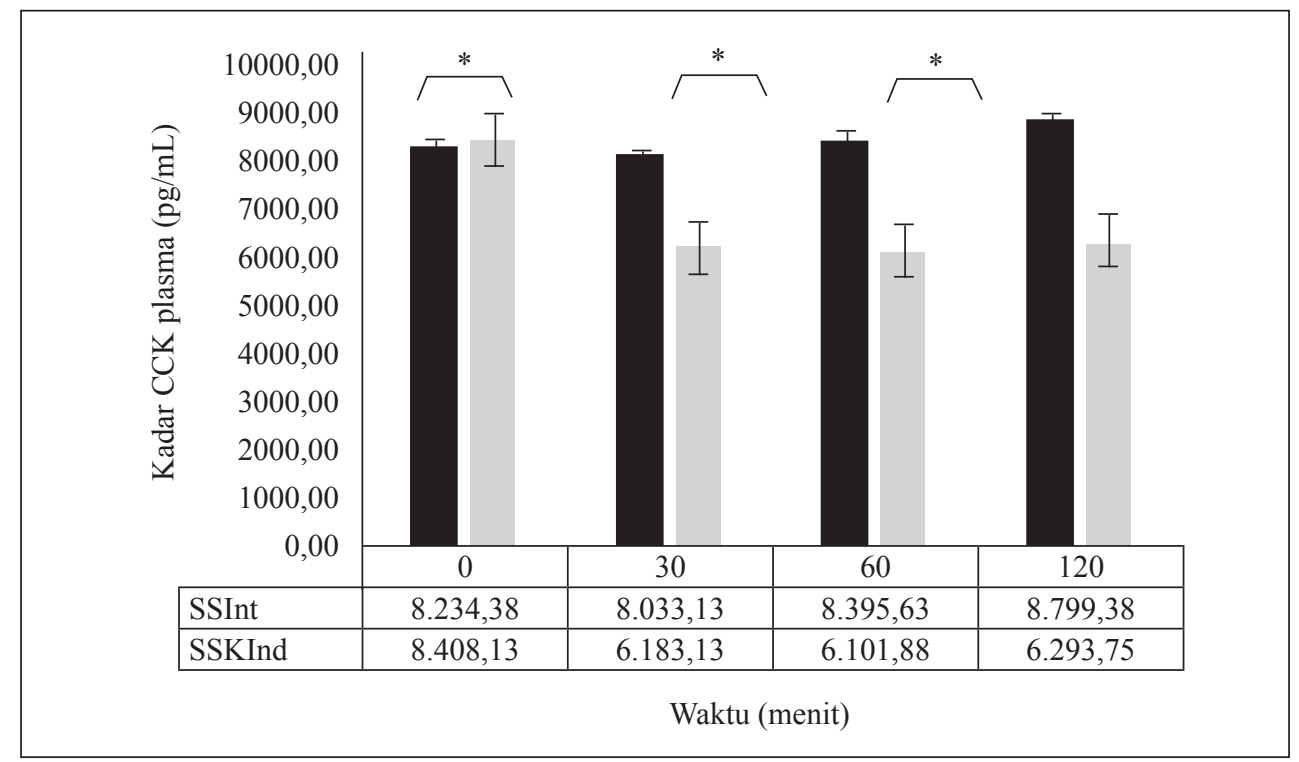

$\mathrm{CCK}=$ kolesistokinin; SSKInd = siap saji khas Indonesia; SSInt = siap saji khas internasional;

* adanya perbedaan yang signifikan $(\mathrm{p}<0,05)$

\section{Gambar 1. Kadar hormon CCK plasma (pg/mL) pada makanan SSInt dan makanan SSInd di Kota Malang}

yang mengkonsumsi makanan SSInt, penurunan kadar CCK terjadi pada menit ke-30 dan mulai mengalami peningkatan pada menit ke-60 hingga 120 . Hasil analisis dengan uji beda menggunakan independent $t$-tes menunjukkan bahwa terdapat perbedaan kadar CCK yang signifikan antara makanan SSKInd dan makanan SSInt setelah dikonsumsi pada menit ke-30, 60 dan 120 $(\mathrm{p}=0,000)$ sedangkan pada menit ke- 0 setelah dikonsumsi tidak terdapat perbedaan $(\mathrm{p}=0,686)$.

\section{BAHASAN}

Kadar CCK setelah mengkonsumsi makanan SSKInd memiliki tren menurun pada menit ke-30 hingga 60. Peningkatan kadar CCK mulai terjadi pada menit ke-120, akan tetapi nilai tersebut masih jauh di bawah kadar CCK basal (menit ke-0). Hal tersebut tidak sejalan dengan teori bahwa kadar CCK dilepaskan setelah makan dengan onset cepat yaitu 15 menit. Pelepasan CCK ini menunjukkan efek terhadap penekanan nafsu makan $(6,8)$. Berdasarkan hasil penelitian tersebut dapat disimpulkan bahwa konsumsi makanan SSInd memberikan respon CCK yang lambat sehingga dimungkinkan memberikan respon kenyang yang rendah.
Berbeda dengan kadar CCK pada responden setelah mengkonsumsi makanan SSKInt yang menunjukkan kadar CCK mengalami penurunan pada menit ke-30 dan mulai mengalami peningkatan pada menit ke-60 hingga 120. Hal tersebut menunjukkan efek rasa kenyang mulai terjadi antara menit ke-60 hingga menit ke-120 setelah makan. Hal ini sejalan dengan penelitian yang dilakukan di Belanda bahwa setelah mengkonsumsi makanan, CCK akan memberikan respon penurunan pada menit ke-30 dan akan mulai meningkat perlahan pada menit ke-45 (9). Menurut beberapa hasil penelitian sebelumnya, CCK menghambat asupan makan dengan menurunkan porsi makan dan durasi makan tetapi tidak untuk waktu makan berikutnya $(10,11)$.

Makanan SSInt yang diberikan pada penelitian ini memiliki kandungan lemak yang tinggi yaitu sebesar 31,6\% total energi. Penelitian sebelumnya juga menunjukkan bahwa pengeluaran lemak dari usus halus mempengaruhi motilitas antropyloroduodenal dan pelepasan CCK (12). Peran lemak pada usus (terutama asam lemak bebas rantai panjang) bertindak melalui CCK peptida sebagai jalur kenyang secara fisiologis. Hal ini didukung oleh hasil literatur review bahwa ketika 
makanan dicerna, beberapa fungsi lemak ini muncul yaitu stimulasi kontraksi kandung empedu dan sekresi eksokrin pankreas, penghambatan pengosongan lambung, dan penghambatan nafsu makan. Hal ini menegaskan bahwa lemak memiliki dampak tinggi terhadap fungsi CCK sebagai sinyal umpan balik positif untuk merangsang proses pencernaan dan sebagai sinyal umpan balik negatif untuk membatasi jumlah makanan yang dikonsumsi selama makan (13).

Makanan SSKInd memiliki rerata kandungan lemak yang lebih rendah dibandingkan makanan SSInt. Kandungan gizi pada makanan sangat berpengaruh terhadap konsentrasi plasma hormon CCK. Beban dan durasi paparan lemak pada usus kecil dapat mempengaruhi motilitas lambung dan pelepasan hormon CCK $(14,15)$. Saat merangsang sekresi CCK, trigliserida harus dihidrolisis menjadi asam lemak dan asam lemak rantai asil harus memiliki minimal 12 atom karbon rantai panjang untuk merangsang CCK (14-16).

Hasil penelitian di Australia juga menyebutkan bahwa lemak dengan asam lemak rantai panjang mengakibatkan konsentrasi CCK lebih tinggi dari lemak dengan asam lemak rantai pendek. Asam lemak dengan rantai panjang (C12) memberikan konsentrasi yang tinggi pada CCK saat 15 menit pertama dan konstan pada menit berikutnya. Namun, pada asam lemak rantai pendek (C10), konsentrasi CCK mencapai puncak pada menit ke-15 tetapi tidak berlangsung lama dan menurun pada menit berikutnya. Asam lemak rantai panjang juga lebih efisien dalam menekan nafsu makan dan asupan energi (14).

Makanan SSKInd dan makanan SSInt memiliki perbedaan yang signifikan dilihat dari kadar CCK plasma pada menit ke-30, 60, dan 120 setelah dikonsumsi. Hal tersebut menunjukkan bahwa makanan SSInt dengan kandungan lemak tinggi dapat menekan nafsu makan lebih cepat dibandingkan dengan makanan SSKInd pada orang dewasa laki-laki dengan status gizi normal.

\section{SIMPULAN DAN SARAN}

Kadar CCK pada orang laki-laki dewasa dengan status gizi normal yang mengkonsumsi makanan siap saji khas Indonesia dan makanan siap saji internasional terdapat perbedaan pada menit ke-30, 60, dan 120 . Perbedaan kadar CCK tersebut dipengaruhi oleh kandungan zat gizi yang terkandung pada makanan siap saji khas Indonesia dan makanan siap saji internasional. Kandungan lemak yang tinggi pada makanan siap saji internasional memberikan respon peningkatan CCK yang besar. Hal tersebut menunjukkan bahwa makanan siap saji internasional memberikan respon kenyang jangka pendek yang cepat. Namun, dalam upaya pencegahan obesitas hasil akhir total energi yang dikonsumsilah yang berperan penting baik dari makanan siap saji internasional maupun makanan siap saji khas Indonesia. Penelitian selanjutnya yang dibutuhkan adalah penelitian efek rasa kenyang pada parameter hormonal lainnya maupun parameter subjektif beserta faktor-faktor yang mempengaruhinya.

\section{UCAPAN TERIMA KASIH}

Terima kasih diucapkan kepada Direktorat Pendidikan Tinggi (DIKTI) yang telah memberikan dana untuk penelitian ini melalui program Penelitian Usulan Perguruan Tinggi dan penulis menyatakan tidak ada konflik kepentingan dengan pihak-pihak yang terkait dalam penelitian ini.

\section{RUJUKAN}

1. Papagiannidou E, Tsipis A, Athanassiadou A, Petrou E, Athanassiadou P. Dietary energy density, satiety and weight management. Open Acces Scientific Report 2013;2(1):1-5.

2. Manson J, Wilett W, Stampfer M, Colditz G, Hunter D, Hankinson S, et al. Body weight and mortality among woman. N Engl J Med 1995;333(11):677-85.

3. Dasar RK. Laporan hasil riset kesehatan dasar (Riskesdas) 2013. Jakarta: Kementerian Kesehatan RI, Kesehatan BPdP; 2013.

4. Jung RT. Obesity as a disease. British Medical Bulletin 1997;53(2):307-21.

5. Rahmawati W, Handayani D. Different recipes and energy density of Indonesia fast food on percentage of indonesian daily value. Obes Control Ther 2014;1(2):1-5.

6. Kopin A, Mathes W, McBride E, Nguyen M, Al-Haider W, Schmitz F, et al. The cholecystokinin-A receptor mediates inhibition of food intake yet is not essential for the maintenance of body weight. J Clin Invest 1999;103(3):383-91. 
7. ElabScience. Product information: human CCK-8 (Cholesystokinin 8) ELISA kit. [series online] 2014 [cited 2016 December 6]. Available from: URL: http://www. elabscience.com/

8. Beinfels M. An introduction to neuronal cholecystokinin. Peptides 2001;22(8):1197-200.

9. Blom W, Lluch A, Stafleu A, Vinoy S, Holst J, Hendriks HF, et al. Effect of a high-protein breakfast on the postprandial ghrelin response. Am J Clin Nutr 2006;83(2):211-20.

10. Bowen J, Noakes M, Trenerry C, Clifton PM. Energy intake, ghrelin, and cholecystokinin after different carbohydrate and protein preloads in overweight men. J Clin Endocrinol Metab 2006;91(4):1477-83.

11. Salmenkallio-Martilla M, Due A, Gunnarsdottir I, Karhunen L, Saarela M, Lyly M. Satiety, weight management and food. Norway: Nordic Innovation Centre; 2008.

12. Pilichiewicz AN, Little TJ, Brennan IM, Meyer JH, Wishart JM, Feinle-Bisset C, et al. Effects of load, and duration, of duodenal lipid on antropyloroduodenal motility, plasma
CCK and PYY, and energy intake in healthy men. Am J Physiol Regul Integr Comp Physiol 2006;290(3):R66877.

13. Beglinger $C$, Degen L. Fat in the intestine as a regulator of appetite-role CCK. Physiology \& Behavior 2004;83(4):617621.

14. Feltrin K, Little T, Meyer J, Horowitz M, Smout A, FeinleBisset $\mathrm{C}$, et al. Effects of intraduodenal fatty acids on appetite, antropyloroduodenal motility, and plasma CCK and GLP-1 in humans vary with their chain length. Am J Physiol Regul Integr Comp Physiol 2004;287(3):R52433.

15. Moran TH, Kinzig KP. Gastrointestinal satiety signals II cholecystokinin. Am J Physiol Gastrointest Liver Physiol 2004;286(2):G183-8.

16. Matzinger D, Degen L, Drewe J, Meuli J, Duebendorfer $\mathrm{R}$, Beglinger $\mathrm{C}$, et al. The role of long chain fatty acids in regulating food intake and cholecystokinin release in humans. Gut 2000;46:688-93. 